OPEN ACCESS

Edited by:

Jun Wu,

University of Michigan, USA

Reviewed by:

Bin Xu,

Virginia Tech, USA

Qin Yang,

University of California Irvine, USA

*Correspondence:

Xiao-Rong Peng

xiao-rong.peng@astrazeneca.com

Specialty section:

This article was submitted to

Cellular Endocrinology,

a section of the journal

Frontiers in Endocrinology

Received: 26 September 2015

Accepted: 28 October 2015

Published: 19 November 2015

Citation:

Peng X-R, Gennemark P,

O'Mahony G and Bartesaghi S (2015) Unlock the Thermogenic Potential of Adipose Tissue: Pharmacological Modulation and Implications for Treatment of Diabetes and Obesity.

Front. Endocrinol. 6:174. doi: 10.3389/fendo.2015.00174

\section{Unlock the Thermogenic Potential of Adipose Tissue: Pharmacological Modulation and Implications for Treatment of Diabetes and Obesity}

\author{
Xiao-Rong Peng ${ }^{1 *}$, Peter Gennemark², Gavin O'Mahony ${ }^{3}$ and Stefano Bartesaghi' \\ ${ }^{1}$ Cardiovascular and Metabolic Diseases IMED Biotech Unit, Diabetes Bioscience Department, AstraZeneca R\&D, Mölndal, \\ Sweden, ${ }^{2}$ Cardiovascular and Metabolic Diseases IMED Biotech Unit, Drug Metabolism and Pharmacokinetics Department, \\ AstraZeneca R\&D, Mölndal, Sweden, ${ }^{3}$ Cardiovascular and Metabolic Diseases IMED Biotech Unit, Medicinal Chemistry \\ Department, AstraZeneca R\&D, Mölndal, Sweden
}

Brown adipose tissue (BAT) is considered an interesting target organ for the treatment of metabolic disease due to its high metabolic capacity. Non-shivering thermogenesis, once activated, can lead to enhanced partitioning and oxidation of fuels in adipose tissues, and reduce the burden of glucose and lipids on other metabolic organs such as liver, pancreas, and skeletal muscle. Sustained long-term activation of BAT may also lead to meaningful bodyweight loss. In this review, we discuss three different drug classes [the thiazolidinedione (TZD) class of PPAR $\gamma$ agonists, $\beta_{3}$-adrenergic receptor agonists, and fibroblast growth factor 21 (FGF21) analogs] that have been proposed to regulate BAT and beige recruitment or activation, or both, and which have been tested in both rodent and human. The learnings from these classes suggest that restoration of functional BAT and beige mass as well as improved activation might be required to fully realize the metabolic potential of these tissues. Whether this can be achieved without the undesired cardiovascular side effects exhibited by the TZD PPAR $\gamma$ agonists and $\beta_{3}$-adrenergic receptor agonists remains to be resolved.

Keywords: brown adipose tissue, thermogenesis, uncoupling protein 1, drug discovery, PPAR $\gamma$ agonists, thiazolidinediones, $\beta_{3}$-adrenergic receptor agonists, FGF21 analogs

\section{INTRODUCTION}

According to the International Diabetes Federation (IDF), 8.3\% of adults worldwide - 370 million people - have type-2 diabetes (T2D), and the number of people with the disease is set to rise beyond 592 million in under 25 years (1). Although there are many drugs available for diabetes, none of them safely and durably prevent or reverse disease progress and its associated comorbidities. Poor diet, sedentary lifestyle, and obesity are considered major risk factors for diabetes. Inappropriate fuel handling by adipose tissue, liver, and skeletal muscle, combined with ectopic lipid deposition in key metabolic organs (such as liver, pancreas, muscle, and heart) have been hypothesized to play a significant role in the development of insulin resistance. Insulin resistance increases the overall burden on $\beta$-cells, which over time leads to $\beta$-cell failure and development of T2D. 
Adipose tissue can be grossly divided into two major depots, white adipose tissue (WAT) and brown adipose tissue (BAT). WAT stores excess energy as triglycerides (TGs), which can be mobilized by lipolysis to generate free fatty acids (FFAs) for use by other tissues. BAT, on the other hand, is the main site of non-shivering thermogenesis (NST), which requires a brown adipocyte-specific protein called uncoupling protein 1 (UCP1).

Non-shivering thermogenesis by BAT is an interesting target for the treatment of metabolic disease due to the high metabolic capacity of BAT. BAT is highly vascularized and richly innervated by sympathetic nerves, and its activation is predominantly regulated by the sympathetic nerve system via $\beta$-adrenergic receptors ( $\beta$-ARs). Enhancing energy expenditure (EE) through activation of NST by $\beta_{3}$-adrenergic receptor $\left(\beta_{3}\right.$-AR) agonists has been investigated as an alternative to inhibition of food intake for bodyweight loss. This has, however, been unsuccessful in human clinical trials. This lack of effect on EE was partly attributed to negligible BAT function in adult humans compared to the situation in rodents.

The rediscovery of BAT in the adult human in 2007, and the subsequent demonstration of functional involvement of human BAT in NST have revitalized this area (2-5). In addition, the presence of brown-like adipocytes in WAT [referred to as beige or brown-in-white (brite) adipocytes] further increased the interest in brown adipocyte biology, as WAT mass is relatively large and any increase in cellular energetics in this tissue may have a significant impact on whole-body metabolism and EE. The beige nomenclature will be used for this review. Utilization of FFAs during NST could lead to depletion of brown and or beige adipocytes' lipid stores, which may result in redistribution of fuels [including glucose and non-esterified fatty acids (NEFA)] toward brown and beige adipocytes. In turn, this could lead to a reduced fuel over-supply to other metabolic organs (heart, skeletal muscle, and liver) and, thus, improved insulin sensitivity (Figure 1).
Transcriptional and hormonal regulation of the "browning" program of adipose stem cells and characterization of the molecular signature have been reviewed extensively elsewhere (6-12). This paper focuses on the metabolic potential of BAT and beige adipocytes, how these systems can be manipulated by pharmacological means, and how to assess if a brown adipocyte phenotype has been achieved by pharmacological intervention. Finally, we discuss the challenges of drug discovery in this area by reviewing three classes of clinically investigated pharmacological agents that regulate various aspects of BAT and beige adipocyte function: thiazolidinedione (TZD) PPAR $\gamma$ agonists, $\beta_{3}$-AR agonists, and fibroblast growth factor 21 (FGF21) analogs.

\section{BROWN ADIPOSE TISSUE IN ADULT HUMANS}

Typically, BAT is located in the interscapular (iBAT), cervical, auxiliary, perirenal and paraaortic areas of animals or human infants (13-15). In adult humans, BAT depots have a diffuse anatomic distribution, with mixtures of white and beige adipocytes, seeming to coexist in close proximity. Beige adipocytes have also been reported to arise in what are normally considered WAT depots (such as inguinal adipose in rodents) in response to various stimuli such as cold, TZDs, and $\beta$-AR agonists (9). In humans, beige adipocytes were found in the WAT of pheochromocytoma patients due to the presence of catecholamine-secreting tumors $(16,17)$ and in the subcutaneous adipose of severely burned patients where heat loss is increased and who experience prolonged adrenergic stress (18). Both lineage-tracing studies and transcriptional profiling of classical brown and beige adipocytes indicate that these two cell types seem to originate developmentally from distinct cell lineages. Classical brown adipocytes in interscapular BAT arise from precursors that are $m y f 5^{+}$, a gene known to be

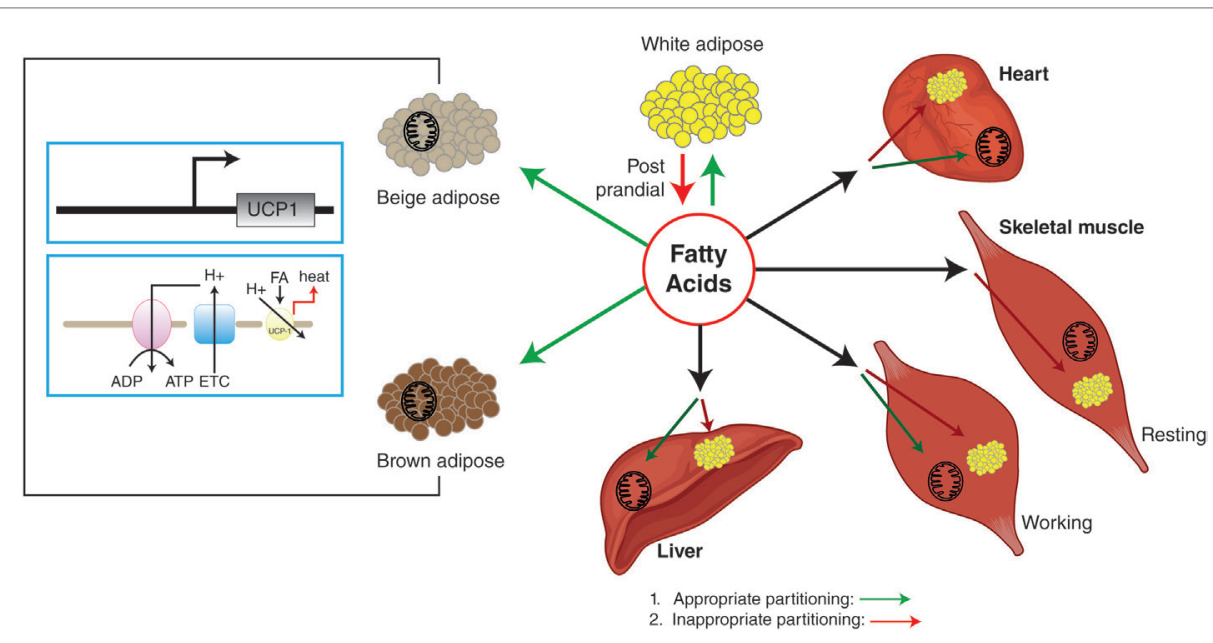

FIGURE 1 | White adipose tissue stores excess energy as triglycerides that can be mobilized by lipolysis to generate FFA for use by other tissues. BAT is the main site of NST, which is carried out by UCP1. Beige adipocytes have uncoupling capabilities similar to brown adipocytes, but are found in what is normally considered WAT. Appropriate partitioning and oxidation of fatty acids into BAT, WAT, beige adipocytes, and other metabolic organs can reduce ectopic fat deposition in metabolic organs, resulting in improved insulin sensitivity. Green arrows indicate appropriate partitioning and red arrows indicate inappropriate partitioning. 
also expressed in committed skeletal muscle precursors $(19,20)$. The developmental origin of the beige adipocyte remains to be elucidated. The whole-body NST will have contributions from both classical brown and beige adipocytes.

It is now beyond doubt that BAT is present in adult humans and plays a role in NST (3). BAT activity can be detected by ${ }^{18} \mathrm{~F}$-fluorodeoxyglucose $\left({ }^{18} \mathrm{~F}-\mathrm{FDG}\right)$ uptake using PET-CT $(2,4$, 5 ). Retrospective analysis of populations that have undergone PET-CT examination indicates that the prevalence of BAT varies between 1 and 5\%. For example, one study on 4011 asymptomatic individuals ( $<5 \%$ obese subjects) showed that BAT prevalence is $5 \%$ in female and $1.3 \%$ in male (21). The BAT-positive subjects had lower body mass index (BMI), less visceral and subcutaneous fat areas, lower fasting glucose and TG levels, and increased HDL cholesterol concentrations compared to the BAT-negative subjects. Similar results were reported for 56 healthy volunteers (22), and for cancer patients $(2,23)$. The inverse correlation between BAT activity and BMI was further confirmed in non-diabetic subjects over a wide range of body compositions (BMI ranging from 22 to $\left.48 \mathrm{~kg} / \mathrm{m}^{2}\right)(4,24-27)$. A recent retrospective analysis of ${ }^{18} \mathrm{~F}-\mathrm{FDG}$ uptake data (analysis of the neck regions of two relatively large cohorts of individuals) reports that the average body weight of BAT-positive individuals is approximately $5 \mathrm{~kg}$ lower compared to that of BAT-negative subjects $(21,23)$.

Using a combination of MRI and molecular analysis, Enerbäck's group clearly demonstrated that iBAT in human infants consists of classical brown adipocytes (15). However, the molecular signature of brown adipocytes isolated from the neck regions of adult humans resembles that of the rodent beige phenotype rather than classical brown adipocytes $(15,28-31)$. What causes the BAT phenotype transformation between infant and adult humans is not understood. It is conceptually important to unravel the function, regulation, and differentiation of beige and classical brown adipocytes in order to be able to pharmacologically enhance thermogenesis in humans. For example, if the adipocytes with various white and beige appearances in adult human neck region are, in fact, simply dormant brown adipocytes, they may be readily re-activated by cold or sympathomimetics. In addition, it is important to understand the translational aspects of BAT biology, i.e., whether the same or different pharmacological agent(s) will show desirable effects in preclinical animal species and man?

\section{BAT AND METABOLIC SIGNIFICANCE}

The contribution of BAT to whole-body metabolism in rodents has recently been examined using tools such as radioactive tracers and PET-CT imaging. Bartelt et al. showed that BAT is the major site of triglyceride-rich lipoprotein (TRL) clearance during acute cold exposure (32). Cold exposure also dramatically increased the glucose disposal to BAT tissue. The remarkable capacity of BAT to take up substrates is illustrated by the ratio of BAT mass to the total glucose and TG uptake by BAT compared to that of other major organs in mice under cold challenge. Labbe et al. extended this observation through PET-CT analysis of the rate of substrate flux and oxidation in the iBAT of both warm- and cold-adapted rats (33). The rate of glucose uptake into iBAT was relatively low at $27^{\circ} \mathrm{C}$ but increased 10-fold upon acute cold exposure and increased 46 -fold after cold acclimation at $10^{\circ} \mathrm{C}$. Similarly, NEFA levels rose 6-fold upon acute cold exposure, and $\sim 100$-fold after cold acclimation. The metabolic activity of the iBAT reached levels similar to that of heart and liver after $6 \mathrm{~h}$ of cold exposure. In spite of these results, it should be kept in mind that although BAT glucose uptake per unit volume of tissue is important, the bulk of glucose turnover during cold exposure is mediated by skeletal muscle metabolic activation even when shivering is minimized (7).

It is more challenging to determine the specific contribution of beige adipocytes to whole-body metabolism. Bartelt et al. showed that acute cold exposure also increases TRL uptake in inguinal WAT (iWAT), but to a smaller extent compared to iBAT (32, 34). Seale's group reported an aP2-PRDM16 transgenic mouse that exhibited a highly favorable metabolic phenotype, in which iBAT remained unchanged but with extensive browning in iWAT. This suggests that beige adipocytes may contribute to the overall metabolic phenotype observed in this mouse (35).

On the whole-body level, Reitman's group dissected the relative contributions of cold-induced, diet-induced, and physical activity-associated EE in mice in relation to the basal metabolic rate (BMR) at various temperatures (36). This work clearly illustrated that at $22^{\circ} \mathrm{C}$, the temperature at which most reported metabolic studies have been conducted, mice expend a relatively large amount of energy to generate heat (120\% of BMR). Adult humans, on the other hand, live in or near their thermoneutral zone, with a relatively small contribution from adaptive thermogenesis to $\mathrm{EE}$ ( $5 \%$ of $\mathrm{BMR}$ ) (11). Interestingly, in mice housed at thermoneutrality $\left(30-32^{\circ} \mathrm{C}\right)$, the relative contributions of BMR, diet, physical activity, and adaptive thermogenesis in mice to overall EE are reported to be $\sim 60,12,25$, and $0 \%$, respectively (36). These figures are very similar to the relative contributions seen in humans with low activity levels, and might represent experimental conditions more suitable for translational research in this field. The EE increase in relation to external temperature is conceptually depicted in Figure 2 (not scaled to real data).

Numerous studies that address the role of human BAT activation and its quantitative impact on whole-body metabolism have been published. Based on the heat production capacity of mouse BAT, Rothwell and Stock proposed in the 1980s that 40-50 g of BAT, if maximally activated, could account for $20 \%$ of daily EE in human (37). More recently PET-CT measurements estimated the average active BAT volume in healthy humans to be $137 \mathrm{~cm}^{3}$, corresponding to a conservative estimate of around $50 \mathrm{~g}$ BAT mass (11). Virtanen et al. estimated the EE of human BAT to be $55 \mathrm{~W} /$ $\mathrm{kg}$ (5) based on the rate of glucose uptake during cold exposure, as measured by dynamic PET-CT. These conservative estimates suggest that the EE of fully activated BAT could amount to $2-5 \%$ of BMR. Recent cold exposure experiments confirmed that the cold-induced NST-associated increase in EE accounts for 0-15\% of BMR (11). Using a human body-composition model (38), we further extrapolated that a $4 \%$ increase of BMR could lead to a $3 \%$ bodyweight reduction per year, assuming that the effects are sustained. A key assumption in such an extrapolation is that functional tolerance can be avoided (39). In support of this assumption, some pieces of evidence suggest that increased thermogenesis is not always fully compensated for and negated by an increase in food intake, for reasons that are not fully understood (40). 


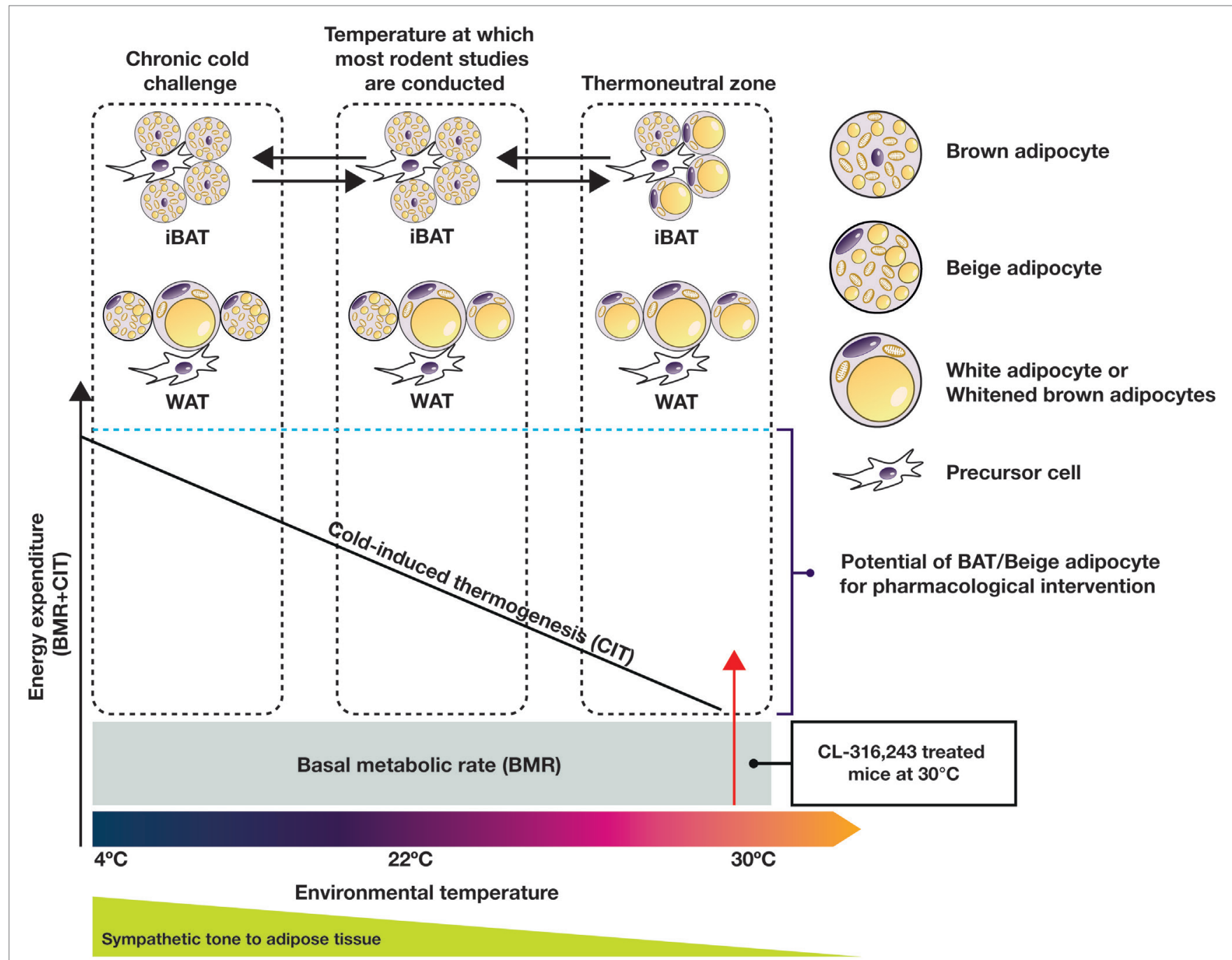

FIGURE 2 | Adaptation of EE and adipose tissue morphology and function to the changes of environmental temperature in the mouse. Sympathetic tone to adipose tissue plays an important role in this process. Most current published rodent studies are conducted at temperatures below the thermoneutral zone, while humans typically live near the thermoneutral zone. For adequate translation between species, rodent studies should be performed under thermoneutral conditions.

Cypess et al. recently reported a $13 \%$ increase in BMR as a result of BAT activation upon administration of an acute dose of the $\beta_{3}$-AR agonist mirabegron (41). Again, assuming that this BMR increase could be sustained upon chronic treatment, modeling suggests that this could potentially lead to an $8 \%$ bodyweight loss per year in BAT-positive healthy men. Besides potential functional tolerance, it remains uncertain if chronic $\beta$-AR-mediated stimulation of BAT is possible without encountering the side effects often associated with $\beta$-AR agonists.

Bodyweight reduction has been shown to have positive effects not only on preventing the progression of pre-diabetes to diabetes, but also leads to a reduction of hemoglobin A1c (HbA1c) (42). More recently, Hanssen et al. showed that 10-day cold acclimation in obese T2D patients could increase BAT activity, which was in turn associated with a reduction of BAT TG content and increased EE (43). One very encouraging observation is the
$43 \%$ improvement of glucose infusion rate during a clamp study. Importantly, the improvement in insulin sensitivity of both adipose and skeletal muscle appeared before any bodyweight change could be seen (43). As indicated by Hanssen et al., the cold-induced improvement in insulin sensitivity exceeds that which was observed after long-term exercise training. To place this in a pharmacological context, this improvement in insulin sensitivity is similar in extent to that seen after 2-week treatment with dapagliflozin (Farxiga/Forxiga), which affords an $18 \%$ improvement in tissue glucose disposal (44).

\section{FUNCTIONAL BROWN/BEIGE ADIPOCYTES}

The remarkable metabolic capacity of classical brown adipocytes in the activated state has been well characterized using rodent 
brown adipocytes. Functional characterization of beige adipocytes from the inguinal adipose tissue of mice or differentiated beige adipocytes from human adipose stem cells suggests that these cells are functionally similar to classical brown adipocytes $(45,46)$. The developmental origin of brown and beige adipocytes is currently an area of intense research and has been extensively reviewed elsewhere $(47,48)$.

Uncoupling of the mitochondrial transmembrane proton gradient in brown adipocytes in order to generate heat in response to cold is a complicated but well-orchestrated event. The key metabolic and signaling pathways in the brown or beige adipocyte are summarized in Figure 3. To be able to carry out this function, brown adipocytes need to be equipped with a complex machinery that is able to (i) signal through norepinephrine (NE) or other catecholamines via $\beta$-ARs, (ii) generate intracellular FFAs through hydrolysis of TGs from lipid droplets (lipolysis), and (iii) uncouple the ATP-generating process via UCP1 activation (13, 49). Chronically, cold challenge leads to a recruitment process in which cell proliferation, mitochondrial biogenesis, and angiogenesis are enhanced. Given the broad range of cellular processes that are involved in these events, it is not surprising that large numbers of genes/factors have been described to regulate the differentiation and function of brown and beige adipocytes $(9,34)$.

The $\beta_{3}$-AR has emerged as a leading molecular target for the activation of brown or beige adipocytes $(18,41)$. Rodent and human adipose tissue display different $\beta$-AR expression profiles. (50-53). In mouse, the $\beta_{3}$-AR is highly expressed in both BAT and WAT with several-fold higher abundance than the $\beta_{1}$-AR, whereas in the adult human, the $\beta_{3}$-AR is only expressed in BAT. In human WAT, $\beta_{1}$-AR has been reported to be 50 -fold more abundant than $\beta_{3}$-AR (52). The $\beta_{3}$-AR subtypes also differ in their potency toward various ligands, G-protein coupling, and desensitization. The binding affinity of $\mathrm{NE}$ to $\beta_{3}$-AR was reported to be in the low micromolar range, while the potency for cAMP accumulation is in the low nanomolar range when measured in intact cells, suggesting that the coupling efficacy to adenylyl cyclase of $\beta_{3}$-AR was higher than that of $\beta_{1}$-AR $(52,54)$. In addition, $\beta_{1}$-AR desensitizes more rapidly than $\beta_{3}$-AR upon exposure to agonists. This led to the hypothesis that $\beta_{1}$-AR may mediate the NE response to low levels of sympathetic stimulation. On the other hand, the activation of $\beta_{3}$-AR may require higher levels of sympathetic stimulation, but once activated this receptor is likely to deliver a more sustained effect (52). It is important to note that circulating NE levels are generally in the low nanomolar concentration range, and it is likely that NE concentrations at the synaptic clefts will be much higher during cold response, providing sufficiently high local concentrations in BAT to enable local activation of $\beta_{3}$-AR in spite of the low plasma concentration. Recently, several studies have shown that systemic administration of adrenergic activators, such as isoproterenol (ISO) and ephedrine, fail to elicit BAT activation in man (55-57). To properly interpret these clinical data, it is crucial to understand if the plasma concentrations of the adrenergic agonists used reached a sufficiently high concentration to enable activation of lipolysis and thermogenesis in human BAT.

Norepinephrine-mediated $\beta$-AR activation results in an increased intracellular cAMP concentration, which in turn stimulates lipolysis in brown adipocytes via activation of the protein kinase A pathway. Lipolysis is a stepwise process with different enzymes acting at each step: TGs are hydrolyzed by desnutrin/adipose triglyceride lipase (ATGL) to form diacylglycerol (DAG). DAG is then hydrolyzed by hormone-sensitive lipase (HSL) to monoacylglycerol and, subsequently glycerol, with a fatty acid released at each stage. Intracellular FFAs are the direct activators of UCP1 (58). In humans, the BAT radiodensity (which is indicative of intracellular TG stores) is inversely correlated with NST, strongly suggesting that depletion of intracellular TG occurs during cold exposure. In rats, inhibition of lipolysis by nicotinic acid-mediated GPR109a agonism significantly reduced the oxidative capacity of iBAT in response to cold, again suggesting a key role for lipolysis in UCP1-mediated thermogenesis (33). Additionally, adipose tissue-specific knockout of ATGL led to the formation of "whitened" brown adipocytes and resulted in impaired lipolysis and defective thermogenesis in BAT (59-62).

The brown adipocytes' cold-depleted energy stores are replenished by de novo lipogenesis and glycogen synthesis, which requires cellular uptake of circulating glucose and FFAs (derived either from TRLs or from lipolysis in WAT). In brown adipocytes, glucose uptake is mostly mediated by glucose transporter 1 (GLUT1) and glucose transporter 4 (GLUT4) and subsequently stored as glycogen or converted to lactate through anaerobic glycolysis. As shown in Figure 3, FFAs are transported into the cell by cluster of differentiation 36 (CD36) and TGs are subsequently synthesized through re-esterification by a series of enzymes, including glycerol-3-phosphate acyltransferase (GPAT) and diacylglycerol O-acyltransferases (DGATs) (49). The process of recruitment of new brown or beige adipocytes and the maintenance of mature adipocyte function during acute and chronic cold acclimation are subject to complex transcriptional and hormonal regulation, for example, by PPAR $\gamma$, bone morphogenic proteins (BMPs), the thyroid axis, and FGF21. These regulatory mechanisms have been extensively reviewed elsewhere $(8,47,48,63)$.

The functional activity of BAT is reduced by chronic warm acclimation, old age, obesity, and diabetes. Rodent models of genetic deficiency of leptin ( $o b / o b, d b / d b$, and obese $f a / f a$ rats) are cold sensitive, and their brown adipocytes have a white adipocyte appearance with reduced expression of UCP1 protein $(64,65)$. Old age and lack of cold challenge also reduce the thermogenic activity of the brown adipocytes (66). Brown adipocytes isolated from guinea pigs housed at $30^{\circ} \mathrm{C}$ appear unilocular, although these cells appear to retain their brown adipocyte identity and are able to respond to NE with a robust increase of thermogenesis, which is not the case for adipocytes isolated from WAT (67). In humans, BAT activity is inversely correlated with age, fat mass, and BMI. Insulin-stimulated glucose uptake is also compromised in the BAT of diabetic individuals (68). Recent reports that both chronic cold acclimation and weight loss can enhance BAT activity in humans are encouraging $(27,69,70)$, indicating that reduced BAT function may be restored. In this respect, adipocytes or adipose precursor cells are highly plastic and able to adapt to the functional needs, as has been shown in rodent using lineage tracing experiments (71). 


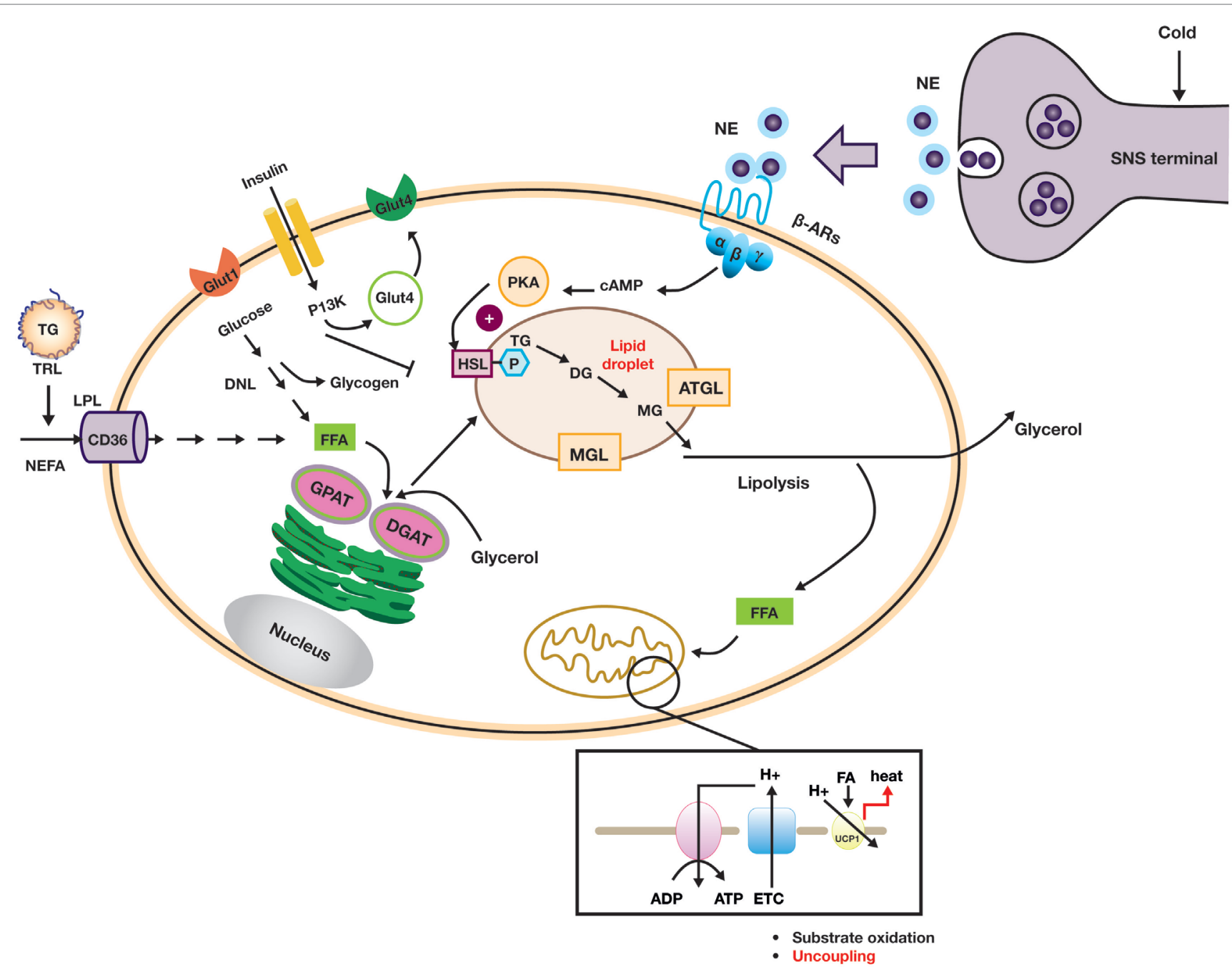

FIGURE 3 | Diagram showing key metabolic and signaling pathways in brown or beige adipocytes.

\section{THIAZOLIDINEDIONES}

The TZDs [represented by rosiglitazone (Avandia) and pioglitazone (Actos)] are a chemical class of PPAR $\gamma$ agonists used as insulin sensitizers for the treatment of T2D (72). The primary site of action of the TZDs is adipose tissue, where they improve several functional aspects, including the uptake and storage of plasma NEFA. They also increase FFA mobilization under fasting conditions and enhance postprandial suppression of FFA mobilization by insulin (73).

Thiazolidinediones have been shown to increase UCP1 expression and BAT mass in rodents. Rosiglitazone has been shown in vitro by several laboratories to induce UCP1 in rodent brown adipocytes and differentiated adipose stem cells (74-77). In addition, chronic treatment of human subcutaneous adipose stem cells with rosiglitazone upregulated several components of the mitochondrial electron transport chain, which is consistent with what has been observed in human (78). The UCP1 protein in human adipocytes differentiated in vitro in the presence of rosiglitazone is only functional when cells have been allowed to differentiate for a longer time than is typically reported in mouse studies (45). Although TZDs have the ability to recruit the "browning program" in both mouse and human adipocytes, the thermogenic capacity of UCP1-expressing cells cannot be unleashed without subsequent activation (e.g., by $\beta$-AR agonists). An increase in the oxygen consumption rate (OCR) of human adipocytes differentiated in vitro in the presence of rosiglitazone could only be observed when the cells were stimulated with isoproterenol or in the presence of exogenously provided FFAs. The increase of OCR in these beige cells is completely UCP1 dependent, as UCP1 knock-down abolishes the effect (45).

Various in vivo rodent models of insulin resistance have been used to show that the TZDs increase UCP1 mRNA in iBAT and overall iBAT weight. However, this is not associated with a subsequent increase in thermogenesis or whole-body EE. In addition, TZD treatment leads to the brown adipocytes becoming lipid filled (79-81). This led to the hypothesis that obese and diabetic animals or humans could first be primed by a PPAR $\gamma$ 
agonist to expand the BAT capacity, followed by its activation via a $\beta$-AR agonist. This concept was tested pre-clinically in $o b / o b$ mice by pre-treating with a PPAR $\gamma$ agonist $(\mathrm{COOH}$, a non-TZD PPAR $\gamma$ agonist) followed by treatment with the $\beta_{3}$-AR agonist CL-316,243. Synergistic effects on EE and bodyweight reduction were indeed observed in this single study (82). However, a later study using rosiglitazone followed by acute cold exposure failed to reproduce these effects (83). A possible explanation for the lack of increased EE in spite of increased TG storage, UCP1 expression and BAT mass induced upon PPAR $\gamma$ activation by rosiglitazone (84) may be the downregulation of $\beta_{3}$-AR and iodothyronine deiodinase type II (DIO2) expression caused by TZD treatment $(85,86)$. In addition, as $\mathrm{COOH}$ belongs to a different structural class of PPAR $\gamma$ agonists to the TZDs, it is not unlikely that different outcomes could be observed between the two compounds. In humans, 12 weeks of pioglitazone treatment has been shown to generate a small increase in UCP1 mRNA levels in subcutaneous adipose tissue (87). However, combined pioglitazone and ephedrine treatment for 12 weeks in obese human subjects failed to deliver significant bodyweight reduction (88).

When comparing the observed outcomes of studies employing PPAR $\gamma$ agonists, it must be kept in mind that even structurally closely related compounds may exhibit very different PPAR $\gamma$ dependent pharmacodynamic profiles. This is, in part, due to ligand-dependent modulation of the PPAR $\gamma$ protein that leads to recruitment of different coactivator and corepressor proteins, in turn resulting in a unique transcriptional profile for each compound (89). Since the identification of PPAR $\gamma$ as the molecular target of the TZDs (90), significant effort has been invested by the pharmaceutical industry in PPAR $\gamma$ agonist drug discovery (91-96) albeit largely without commercial success (97). The availability and high throughput of PPAR $\gamma$ LBD-based ligand binding assays and chimeric PPAR $\gamma-$ GAL4 reporter gene/transactivation assays enabled the generation of many highly potent, structurally diverse, selective PPAR $\gamma$ full and partial agonists. Despite this, since the launch of pioglitazone and rosiglitazone, no new selective PPAR $\gamma$ agonists have survived clinical testing and remain on the market, mainly due to preclinical and clinical safety issues (98-101). The central role of PPAR $\gamma$ in adipose biology has, however, not diminished due to these failures and PPAR $\gamma$ remains an attractive but challenging drug target.

The lack of translation between in vitro receptor binding and the functional (both in vitro and in vivo) effects of the compounds and inter-species differences in PPAR $\gamma$ biology are considered major obstacles in this field. This is due to a number of factors, including the combinatorial nature of the activation of the PPAR $\gamma:$ RXR heterodimer $(102,103)$, subtle differences in coactivator/corepressor recruitment between superficially related compounds (104-107), ligand effects on the extent of posttranslational modifications $(108,109)$, and non-transcriptional effects of the ligands (72). This suggests that a reductionist approach to $\operatorname{PPAR} \gamma$ agonist discovery based on the use of isolated protein domains and chimeric reporter gene assays is unlikely to provide compounds with the desired functional or clinical outcome.

Since the "traditional" approach of optimizing receptor binding and agonist potency has not borne fruit, a radical change in the preclinical approach to PPAR $\gamma$ drug discovery is needed in order for the functional potential (for example, browning of WAT) of small-molecule PPAR $\gamma$ activation to be realized. For example, the application of phenotypic screening in relevant cell systems [i.e. primary human cells (110)] is one approach to frontload the functional assessment of compounds, with traditional in vitro assessment of PPAR $\gamma$ activity included in a secondary wave of assays. In addition, the recent widespread availability of omics techniques (such as RNAomics and proteomics) makes the preclinical identification of PPAR $\gamma$ agonists with a desirable functional profile a realistic prospect. A combination of such approaches avoids focus on a single receptor-dependent pathway or mechanism and allows pleiotropy to be accounted for. However, whether the perceived target-related risk associated with PPAR $\gamma$ agonism is considered acceptable in proportion to the potential commercial viability of a safe PPAR $\gamma$ agonist remains to be seen.

\section{BETA-3 ADRENERGIC RECEPTOR}

Several sympathomimetic $\beta_{3}$-AR agonists that selectively stimulate rodent brown and white adipocyte lipolysis were discovered from the mid-1980s onward (e.g., BRL-37344, CL-316,243, and CGP12177A) $(50,51,111)$. Early optimization of these compounds was mostly performed in rodent tissue or cell models, as the human $\beta_{3}$-AR was not cloned until 1989 (112). The compounds showed potent anti-obesity and anti-diabetic effects in rodent models of obesity and diabetes, but none of these compounds advanced beyond the clinical phase II due to lack of efficacy. Specifically, compounds optimized using rodent $\beta_{3}$-AR did not effectively translate to human. Several $\beta_{3}$-AR agonists were synthesized and evaluated after the cloning of human $\beta_{3}$-AR cDNA (113). A summary of studies investigating the effect of $\beta_{3}$-AR agonism on EE in man is given in Table 1. Note that many binding and adenylyl cyclase activity assays were performed using isolated membrane preparations, returning $\beta_{3}$-AR binding affinities in the micromolar range for the compounds tested. Lower potencies (in the nanomolar range) have been reported for the same compounds when measured in whole-cell assays (cAMP, lipolysis, or respiration) (52), suggesting a G-protein coupling efficiency for the $\beta_{3}$-AR that is only captured in a whole-cell context.

Most early human trials of $\beta_{3}$-AR agonists used bodyweight reduction as a clinical endpoint, to be achieved through increased EE. Data on BAT activation and metabolic parameters are scarce, with the exception being for the CL-316,243 study (124). In this study, treatment of lean healthy men for 4 weeks did not increase $\mathrm{EE}$, but resulted in a $45 \%$ increase of insulin-mediated glucose disposal and a reduced $24-\mathrm{h}$ respiratory quotient (24-h RQ), indicating enhanced fat oxidation. Intriguingly, CL-316,243 significantly increased fasting FFA levels in parallel with improved insulin action. These data are in line with recently published improved glucose infusion rates in T2D patients after 10 days of mild cold exposure (43). In both cases, improved insulin action preceded any significant weight loss. This improved action of insulin may be due to partitioning of FFAs toward BAT, which in turn reduces the fatty acid burden on other metabolic tissues (see Figure 1). Indeed, improved glucose uptake was seen in the skeletal muscle of T2D patients after cold exposure (43). 
TABLE 1 | In vitro properties of $\beta_{3}$-adrenergic receptor agonists that have been tested in humans, and their effect on energy expenditure in man.

PHYSICAL AND PHARMACOKINETIC PROPERTIES

$\begin{aligned} & \text { Compound } \\ & \text { name(s) and } \\ & \text { chemical } \\ & \text { structure }\end{aligned}$
$\mathrm{CL}-316,243$

structure

$466.8\left(\mathrm{Na}_{2}\right.$ salt), 421.8 (free $\quad 418.5$

$\mathrm{MW}(\mathrm{g} / \mathrm{mol})$

$$
\text { acid) }
$$

clogP

$$
-1.4
$$

potency/TE

$\mathrm{EC}_{50} 1.15 \mu \mathrm{M} / 0.63^{\mathrm{a}}(114)$

potency/T

Rodent $\beta_{3}$

Rat $K_{\mathrm{i}} 1 \mu \mathrm{M}, K_{\text {act }} 0.71 \mathrm{nM} / 1^{\mathrm{a}}$ in

$\beta_{3}$ overexpressing $\mathrm{CHO}$ cells

(111)

Fold selectivity $\quad 1: 228: 96$

Based on $\mathrm{CHO}$ data (114).

Reported as an antagonist @ $\beta_{1}$ and $\beta_{2}$ (120)

$T_{1 / 2} / \% \mathrm{~F}$

$16 \mathrm{~h} / 10 \%$ (human)

315.4

$-0.3$

$K_{\text {act }} 20$ nM (for ZD201651, the major active metabolite) (115)

$-$

Obese men and women (115)

Obese men and women with BMl $27-39$ kg/m² (115)

Administration

$1.5 \mathrm{~g} /$ day for 8 weeks $(n=10)$

$150 \mathrm{mg} /$ day for 2 weeks $(n=$ $(n=9)$

Placebo $(n=4)$

$300 \mathrm{mg} /$ day for 2 weeks $(n=8) \quad$ Placebo $(n=8)$ Placebo $(n=22)$

Exposure

$30 \pm 11 \mathrm{nM}$ (steady-state $\left.C_{\min }\right)$

Fold in vitro $\mathrm{EC}_{50} \quad<0.1$

BAT activity

Energy

24-h EE after 8 weeks did not

$-$

expenditure differ from baseline with BMI $27-39 \mathrm{~kg} / \mathrm{m}^{2}$

\section{L-796568

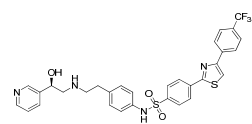

$>8 \mathrm{~h} / 17 \%$ (rat)
$\left.C_{\text {min }}\right)$

-
-
-
Trend for stimulatory
effect on 24-h EE (2.4\%)

Mean change in 24-h EE

significantly between treated and placebo

$>20$
624.7

5.3

$3.6 \mathrm{nM} / 0.94^{\mathrm{a}}(117)$

1:667 (partial):1333 (partial)

209 (partial):1032 (partial)

Healthy overweight to obese men (121)

$375 \mathrm{mg} /$ day for 28 days

$(n=10)$

Placebo $(n=10)$

$77 \pm 30 \mathrm{nM}$ (steady-state

upon treatment did not differ

\section{TAK-677 (Rafabegron)}

III

Mirabegron (YM-178)

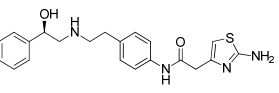

402.9 (free acid)

396.5

0.7

1.3

$\mathrm{EC}_{50} 0.062 \mathrm{nM} / 1.16^{\mathrm{a}}(118) \quad 22 \mathrm{nM} / 0.8^{\mathrm{a}}(119)$

$0.016 \mathrm{nM} / 1.1^{\text {a }}$ (rat cAMP)

1:>446 (partial):>446 (partial)

$>1000$

Obese men and women, mean Healthy male subjects with BMI $33.9 \mathrm{~kg} / \mathrm{m}^{2}$ (122) detectable BAT (41)

$0.5 \mathrm{mg}$ BID for 29 days

$(n=22)$

200 mg acutely $(n=12$ crossover study)

Placebo $(n=4)$

$24 \pm 13 \mathrm{nM}($ at $t=2 \mathrm{~h})$

$781 \pm 184 \mathrm{nM}\left(C_{\max }\right)$

$>30$

Significant increase in BAT glucose uptake, from 1 to $130 \mathrm{~mL} \times S U V_{\text {mean }} \times \mathrm{g} / \mathrm{mL}$

Slight increase ( $50 \mathrm{kcal} /$ day) Increased resting metabolic in 24-h EE at the highest dose rate by $203 \pm 40 \mathrm{kcal} / \mathrm{day}$

$(+13 \% ; p=0.001)$ 


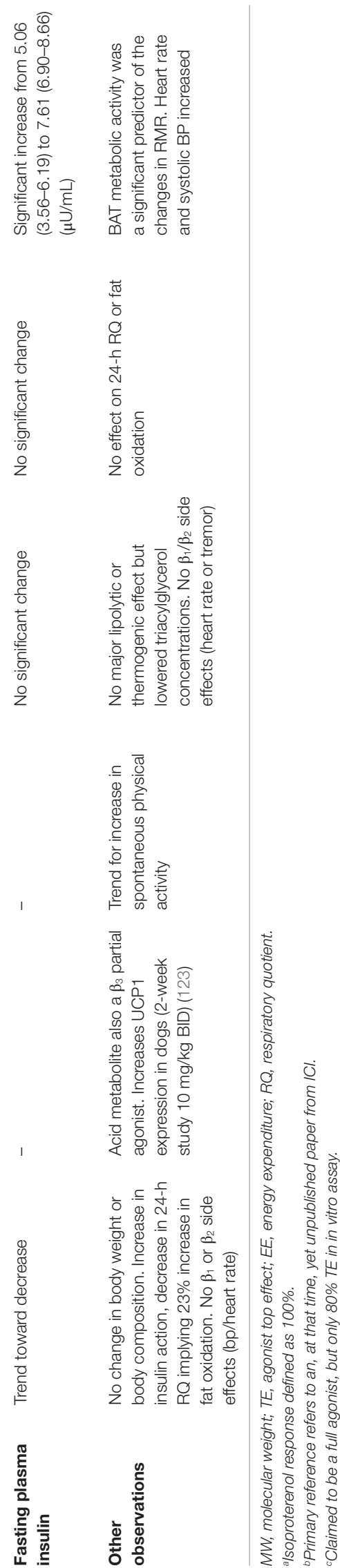

Similarly to CL-316,243 treatment, chronic dosing of the $\beta_{3^{-}}$ AR agonists ZD7114 and ZD2079 did not significantly increase $\mathrm{EE}$, although the latter compound showed a tendency toward a non-statistically significant increase of $2 \%$ (115).

Data have been reported for both acute and chronic dosing of $\beta_{3}$-AR agonist L-796568 in overweight to obese men. Acutely, van Bak et al. (125) reported a significant increase (8\%) in EE after $4 \mathrm{~h}$ for the highest dose used. However, no average increase was observed over the period of observation, 0-4 h. Chronic dosing of L-796568 for 4 weeks did not result in any significant change in EE (121). The authors discuss possible reasons for this lack of effect, e.g., declining plasma exposure levels over time, insufficient agonist-induced BAT proliferative capability of $\beta_{3}$ AR-responsive tissues in humans during chronic stimulation, potential downregulation of $\beta_{3}$-AR receptors, or other functional feedback. We believe that the small effect on EE observed in the acute study is another reason.

A chronic $\beta_{3}$-AR agonism study (using TAK-677) in obese humans with no observed effect on EE or diabetic parameters was reported by Redman et al. (122). Whether BAT activation truly occurred after administration of compound was not carefully assessed in this study, which makes data interpretation challenging.

In contrast to the above-mentioned $\beta_{3}$-AR agonism studies, Cypess et al. recently reported a $\sim 13 \%$ increase in resting metabolic rate (RMR) upon acute treatment with high doses of $\beta_{3}$-AR agonist mirabegron (41). In this study, healthy young male subjects with detectable BAT were selected in order to provide proof of concept (PoC) for $\beta_{3}$-AR agonist-mediated BAT activation. Importantly, it was found that BAT metabolic activity was a significant predictor of the changes in RMR. This study also reports a weak correlation between cold- and drug-induced detectable BAT activities. Generally, such data from the same individuals are important to help put the large quantity of cold-induced BAT activation data into a drug-discovery context. It remains to be investigated if the reported energy-expenditure effect is sustained upon chronic dosing and if the efficacy of mirabegron will persist in females and other patient subpopulations, such as those with different ages and BMIs.

The failure of $\beta_{3}$-AR agonists to show clinical effects on weight loss decreased interest in the mechanism as a means of treating the metabolic syndrome. However, the recent rediscovery of BAT in adult humans as well as the demonstration of functional activation of BAT by a $\beta_{3}$-AR agonist may lead to a resurgent interest in $\beta_{3}$-AR agonists for the treatment of metabolic disorders. The observation that improved insulin action preceded any significant weight loss upon $\beta_{3}$-AR agonist treatment is particularly encouraging.

Clearly, important questions remain unanswered with respect to the role of the $\beta_{3}$-AR and the clinical profile of $\beta_{3}$-AR agonists. In order to make significant progress in $\beta_{3}$-AR drug discovery, the lack of translation from rodent to human (i.e., receptor expression and functional differences) and from in vitro to in vivo for the human setting needs to be resolved. The clinically assessed $\beta_{3}$-AR agonists exhibit structural and physicochemical property diversity; however, clinical plasma exposures relative to $\mathrm{EC}_{50}$ are similar for the chronic and acute studies (Table 1), and activation 
of BAT would therefore be expected in the chronic studies. The lack of effect on EE observed in the chronic studies may either be due to not measuring a mechanism-relevant clinical endpoint or that the patients recruited lacked sufficient BAT to lead to an effect on overall EE. The activation of pre-existing BAT by $\beta_{3}$-AR agonists may require a personalized healthcare approach, unless combined with a compound or mechanism to expand the BAT depot.

Finally, cardiovascular side effects have been associated with $\beta_{3}$-AR agonist treatment, usually attributed to insufficient selectivity toward the $\beta_{1}$ - and $\beta_{2}$-ARs. However, the in vitro functional activity of many of the clinical compounds assessed does not explain the increase in heart rate observed - several of the compounds are functional $\beta_{1}$-AR antagonists ( $\beta_{1}$-AR blockers), and as such could be expected to have the opposite effect to that clinically observed. The complex nature of AR biology needs to be further investigated if this mechanism is to be reconsidered as a means of activating BAT.

\section{FIBROBLAST GROWTH FACTOR 21}

Fibroblast growth factor 21 (FGF21) is a member of the endocrine FGF 19/21/23 family. FGF21 protein is expressed in liver, pancreas, and adipose tissue and is regulated by fasting, ketogenic diet, low protein diet, PPAR $\gamma$, and PPAR $\alpha$ activation as well as glucagon action (126). It acts through binding to a cell-surface receptor complex composed of conventional FGF receptors (FGFR1c/2c/3c) and the co-factor $\beta$-Klotho, leading to activation of FGF receptor substrate $2 \alpha$ and ERK1/2 phosphorylation. While FGF receptors are ubiquitously expressed, $\beta$-Klotho expression is restricted to a few tissues, including BAT, WAT, and liver $(127,128)$, which are the main sites of FGF21 action. When administered pharmacologically, FGF21 enhances EE and insulin sensitivity, reduces bodyweight, glucose, and lipids, and thus has the potential to be used for treatment of the metabolic syndrome via multiple mechanisms (129-131).

Functional enhancement of existing BAT and recruitment of beige adipocytes have been hypothesized to be the mechanism behind the EE increase, bodyweight loss, and improved glucose and lipid homeostasis induced by FGF21. FGF21 expression is increased in BAT upon cold challenge $(132,133)$. Adiposederived FGF21 acts in an autocrine/paracrine manner to increase expression of UCP1 and other thermogenic genes, such as $P G C 1 \alpha$, PRDM16, BMP8b, and DIO2 in iBAT and iWAT $(134,135)$. In neonates, FGF21 expression in liver is increased by suckling, which occurs via activation of PPAR $\alpha$, leading to induced BAT thermogenesis (136).

Attempts have been made to directly assess the contribution of BAT and beige adipocytes to FGF21-mediated effects. Surgical resection of iBAT in two different mouse models showed that FGF21-mediated EE increase and bodyweight reduction were retained $(137,138)$. However, one of the studies showed that several beige adipocyte markers, including $P P A R \gamma$, PRDM16, PGC1 $\alpha$, and CIDEA tended toward upregulation in subcutaneous adipose tissue, and perigonadal adipose weight also was reduced (138). The authors propose that residual BAT and beige adipocytes may have compensated for the loss of iBAT. Recently, the role of UCP1 in mediating the pharmacological effects of FGF21 was assessed by treating UCP1 knockout (UCP1 KO) mice with either recombinant FGF21 or FGF21 fused with fragment crystallizable region (Fc-FGF21) (139, 140). Surprisingly, several FGF21-mediated effects were largely retained in the absence of UCP1. Again, compensatory mechanisms seem to be activated in UCP1 KO mice treated with recombinant FGF21. In FGF21-treated UCP1 KO mice, reduced food intake offset the decrease in $\mathrm{EE}$ and resulted in a similar bodyweight reduction to that observed in FGF21treated wild-type mice. In addition, genes regulating fatty acid metabolism were upregulated in liver and epididymal adipose tissue, suggesting that FGF21 recruits UCP1-independent pathways in these tissues to compensate for the lack of UCP1. An intriguing observation was a two- to threefold increase in FGF21 secretion in iBAT when UCP1 KO mice were challenged by cold, suggesting that FGF21 may be one of the factors that recruit alternative thermogenic mechanisms when iBAT/UCP1 fails to generate heat. It should be noted that many previous publications have showed remodeling of the WAT in UCP1 KO mice, and that alternative thermogenic mechanisms have been discussed $(141,142)$.

In spite of the attractive metabolic effects of FGF21, development of FGF21-based therapeutics has encountered several technical challenges, including short in vivo half-life and poor biophysical properties of FGF21 protein (e.g., it is prone to aggregation). To date, three different analogs of FGF21 have advanced to concept testing in human: $(130,143,144)$ (i) LY2405319 (an aggregation-resistant FGF21 analog), (ii) PF-05231023 (FGF21 linked to a Fab fragment of a scaffold antibody), and (iii) ARX618 (PEGylated FGF21). For both LY2405319 and PF-05231023, the effects on TG (close to $50 \%$ reduction in 28 days), LDL cholesterol, and HDL cholesterol were substantial and bodyweight reduction was significant. However, the failure of FGF21 analogs to achieve clinically meaningful glucose-lowering effects was unexpected, and the mechanism behind this remains to be understood. Recently, Genentech reported a bispecific monoclonal antibody agonist that binds to both FGFR1c and $\beta$-Klotho, with sustained effects on NST, EE, and bodyweight over a 35-day period after a single administration to diet-induced obese mice (145). The effects on glucose and lipids were similar to those observed after administration of recombinant FGF21, and mostly attributed to peripheral FGF21 action as CNS exposure of the antibody was reported to be minimal. Together, these data further support the importance of BAT function in FGF21 action. As for the $\beta_{3}$-AR agonist story, it may be important for future clinical concept testing to assess BAT recruitment/activation in order to understand if sufficiently high FGF21 levels have been achieved in patients. In addition, it is critical to constantly monitor potential safety concerns of this treatment principle in all studies, including bone density, growth hormone resistance, and female fertility.

\section{PERSPECTIVES}

The understanding of BAT physiology has increased rapidly in recent years. Data generated in both rodents and humans in 
cold/warm acclimation studies suggest that both BAT and beige adipocytes demonstrate recruitability and plasticity, which opens the door to pharmacological intervention. As obese and T2D patients are likely to have reduced BAT function, in order to realize the full potential of NST, it may be necessary to first restore the function of "whitened" brown or beige adipocytes before activation (Figure 2). In this respect, future studies using rodent models require consideration of external temperature in order to more closely mimic human physiology. Cold acclimation for a short duration in obese and diabetic humans indicates that it is possible to enhance BAT activity and achieve an improved metabolic profile before significant bodyweight reduction occurs. The improved insulin action in the absence of bodyweight change seen in the 4-week treatment of healthy individuals by CL-316,243 (124) suggests that restoration of BAT function may at least lead to improved metabolic control in patients with T2D. Acute treatment of BAT-positive human subjects with the $\beta_{3}$-AR agonist mirabegron resulted in a significant increase in EE. If this effect is sustained upon chronic dosing and without eliciting cardiovascular side effects, this mechanism may finally lead to significant weight loss.

PPAR $\gamma$ remains an interesting target for the recruitment of BAT or beige adipocytes, although discovery of a compound that does not impair the adrenergic sensitivity or thyroid function of the adipocyte is extremely challenging. Phenotypic screening,

\section{REFERENCES}

1. IDF DIABETES ATLAS Sixth edition (2013). Available from: https://www. idf.org/sites/default/files/EN_6E_Atlas_Full_0.pdf

2. Cypess AM, Lehman S, Williams G, Tal I, Rodman D, Goldfine AB, et al. Identification and importance of brown adipose tissue in adult humans. N Engl J Med (2009) 360:1509-17. doi:10.1056/NEJMoa0810780

3. Nedergaard J, Bengtsson T, Cannon B. Unexpected evidence for active brown adipose tissue in adult humans. Am J Physiol Endocrinol Metab (2007) 293:E444-52. doi:10.1152/ajpendo.00691.2006

4. van Marken Lichtenbelt WD, Vanhommerig JW, Smulders NM, Drossaerts JM, Kemerink GJ, Bouvy ND, et al. Cold-activated brown adipose tissue in healthy men. N Engl J Med (2009) 360:1500-8. doi:10.1056/ NEJMoa0808718

5. Virtanen KA, Lidell ME, Orava J, Heglind M, Westergren R, Niemi T, et al. Functional brown adipose tissue in healthy adults. N Engl J Med (2009) 360:1518-25. doi:10.1056/NEJMoa0808949

6. Betz MJ, Enerback S. Human brown adipose tissue: what we have learned so far. Diabetes (2015) 64:2352-60. doi:10.2337/db15-0146

7. Blondin DP, Labbe SM, Phoenix S, Guerin B, Turcotte EE, Richard D, et al. Contributions of white and brown adipose tissues and skeletal muscles to acute cold-induced metabolic responses in healthy men. J Physiol (2015) 593:701-14. doi:10.1113/jphysiol.2014.283598

8. Chechi K, Carpentier AC, Richard D. Understanding the brown adipocyte as a contributor to energy homeostasis. Trends Endocrinol Metab (2013) 24:408-20. doi:10.1016/j.tem.2013.04.002

9. Harms M, Seale P. Brown and beige fat: development, function and therapeutic potential. Nat Med (2013) 19:1252-63. doi:10.1038/nm.3361

10. Nedergaard J, Cannon B. The browning of white adipose tissue: some burning issues. Cell Metab (2014) 20:396-407. doi:10.1016/j.cmet.2014.07.005

11. van Marken Lichtenbelt WD, Schrauwen P. Implications of nonshivering thermogenesis for energy balance regulation in humans. Am J Physiol Regul Integr Comp Physiol (2011) 301:R285-96. doi:10.1152/ajpregu.00652.2010 for example a screen based on human brown adipocyte function, may however facilitate the discovery of such a compound.

Finally, if an FGF21 analog with appropriate half-life and potency could be developed, it would enable PoC testing in humans in order to understand if the potential beneficial metabolic effects of this hormone can be realized.

\section{AUTHOR CONTRIBUTIONS}

XP: conception, structure and content of the text, including the figures. PG: mathematical modeling of the literature data and critical examination and interpretation of pharmacokinetic and pharmacodynamic data on the $\beta_{3}$-AR agonists in clinical studies. Major contribution to the Table 1. GO'M critical review and interpretation of PPAR $\gamma$ and $\beta_{3}$-AR agonists structure, physiochemical properties and assays used for generating the data of all compounds included in Table 1. SB: critical review of bioenergetic of cell biology, general contribution of bioscience-related text, and critical reading and editing of review.

\section{ACKNOWLEDGMENTS}

The authors would like to thank Nick Oakes (AstraZeneca) for his contribution to Figure 1.

12. Vosselman MJ, van Marken Lichtenbelt WD, Schrauwen P. Energy dissipation in brown adipose tissue: from mice to men. Mol Cell Endocrinol (2013) 379:43-50. doi:10.1016/j.mce.2013.04.017

13. Cannon B, Nedergaard J. Brown adipose tissue: function and physiological significance. Physiol Rev (2004) 84:277-359. doi:10.1152/physrev.00015.2003

14. Enerback S. Human brown adipose tissue. Cell Metab (2010) 11:248-52. doi:10.1016/j.cmet.2010.03.008

15. Lidell ME, Betz MJ, Dahlqvist Leinhard O, Heglind M, Elander L, Slawik M, et al. Evidence for two types of brown adipose tissue in humans. Nat Med (2013) 19:631-4. doi:10.1038/nm.3017

16. Frontini A, Vitali A, Perugini J, Murano I, Romiti C, Ricquier D, et al. Whiteto-brown transdifferentiation of omental adipocytes in patients affected by pheochromocytoma. Biochim Biophys Acta (2013) 1831:950-9. doi:10.1016/j. bbalip.2013.02.005

17. Ricquier D, Nechad M, Mory G. Ultrastructural and biochemical characterization of human brown adipose tissue in pheochromocytoma. J Clin Endocrinol Metab (1982) 54:803-7.

18. Sidossis LS, Porter C, Saraf MK, Borsheim E, Radhakrishnan RS, Chao $\mathrm{T}$, et al. Browning of subcutaneous white adipose tissue in humans after severe adrenergic stress. Cell Metab (2015) 22:219-27. doi:10.1016/j. cmet.2015.06.022

19. Seale P, Bjork B, Yang W, Kajimura S, Chin S, Kuang S, et al. PRDM16 controls a brown fat/skeletal muscle switch. Nature (2008) 454:961-7. doi:10.1038/ nature 07182

20. Timmons JA, Wennmalm K, Larsson O, Walden TB, Lassmann T, Petrovic N, et al. Myogenic gene expression signature establishes that brown and white adipocytes originate from distinct cell lineages. Proc Natl Acad Sci U S A (2007) 104:4401-6. doi:10.1073/pnas.0610615104

21. Wang Q, Zhang M, Xu M, Gu W, Xi Y, Qi L, et al. Brown adipose tissue activation is inversely related to central obesity and metabolic parameters in adult human. PLoS One (2015) 10:e0123795. doi:10.1371/journal.pone.0123795

22. Saito M, Okamatsu-Ogura $\mathrm{Y}$, Matsushita M, Watanabe K, Yoneshiro T, Nio-Kobayashi J, et al. High incidence of metabolically active brown adipose 
tissue in healthy adult humans: effects of cold exposure and adiposity. Diabetes (2009) 58:1526-31. doi:10.2337/db09-0530

23. Persichetti A, Sciuto R, Rea S, Basciani S, Lubrano C, Mariani S, et al. Prevalence, mass, and glucose-uptake activity of (1)(8)F-FDG-detected brown adipose tissue in humans living in a temperate zone of Italy. PLoS One (2013) 8:e63391. doi:10.1371/journal.pone.0063391

24. Lee P, Greenfield JR, Ho KK, Fulham MJ. A critical appraisal of the prevalence and metabolic significance of brown adipose tissue in adult humans. Am J Physiol Endocrinol Metab (2010) 299:E601-6. doi:10.1152/ ajpendo.00298.2010

25. Lee P, Swarbrick MM, Zhao JT, Ho KK. Inducible brown adipogenesis of supraclavicular fat in adult humans. Endocrinology (2011) 152:3597-602. doi:10.1210/en.2011-1349

26. Ouellet V, Labbe SM, Blondin DP, Phoenix S, Guerin B, Haman F, et al. Brown adipose tissue oxidative metabolism contributes to energy expenditure during acute cold exposure in humans. J Clin Invest (2012) 122:545-52. doi:10.1172/JCI60433

27. Vijgen GH, Bouvy ND, Teule GJ, Brans B, Hoeks J, Schrauwen P, et al. Increase in brown adipose tissue activity after weight loss in morbidly obese subjects. J Clin Endocrinol Metab (2012) 97:E1229-33. doi:10.1210/ jc.2012-1289

28. Cypess AM, White AP, Vernochet C, Schulz TJ, Xue R, Sass CA, et al. Anatomical localization, gene expression profiling and functional characterization of adult human neck brown fat. Nat Med (2013) 19:635-9. doi: $10.1038 / \mathrm{nm} .3112$

29. Jespersen NZ, Larsen TJ, Peijs L, Daugaard S, Homoe P, Loft A, et al. A classical brown adipose tissue mRNA signature partly overlaps with brite in the supraclavicular region of adult humans. Cell Metab (2013) 17:798-805. doi:10.1016/j.cmet.2013.04.011

30. Sharp LZ, Shinoda K, Ohno H, Scheel DW, Tomoda E, Ruiz L, et al. Human BAT possesses molecular signatures that resemble beige/brite cells. PLoS One (2012) 7:e49452. doi:10.1371/journal.pone.0049452

31. Wu J, Bostrom P, Sparks LM, Ye L, Choi JH, Giang AH, et al. Beige adipocytes are a distinct type of thermogenic fat cell in mouse and human. Cell (2012) 150:366-76. doi:10.1016/j.cell.2012.05.016

32. Bartelt A, Bruns OT, Reimer R, Hohenberg H, Ittrich H, Peldschus K, et al. Brown adipose tissue activity controls triglyceride clearance. Nat Med (2011) 17:200-5. doi:10.1038/nm.2297

33. Labbe SM, Caron A, Bakan I, Laplante M, Carpentier AC, Lecomte R, et al. In vivo measurement of energy substrate contribution to cold-induced brown adipose tissue thermogenesis. FASEB J (2015) 29:2046-58. doi:10.1096/ f.14-266247

34. Bartelt A, Heeren J. Adipose tissue browning and metabolic health. Nat Rev Endocrinol (2014) 10:24-36. doi:10.1038/nrendo.2013.204

35. Seale P, Conroe HM, Estall J, Kajimura S, Frontini A, Ishibashi J, et al. Prdm16 determines the thermogenic program of subcutaneous white adipose tissue in mice. J Clin Invest (2011) 121:96-105. doi:10.1172/JCI44271

36. Abreu-Vieira G, Xiao C, Gavrilova O, Reitman ML. Integration of body temperature into the analysis of energy expenditure in the mouse. Mol Metab (2015) 4:461-70. doi:10.1016/j.molmet.2015.03.001

37. Rothwell NJ, Stock MJ. Whither brown fat? Biosci Rep (1986) 6:3-18. doi:10.1007/BF01145174

38. Hall KD, Sacks G, Chandramohan D, Chow CC, Wang YC, Gortmaker SL, et al. Quantification of the effect of energy imbalance on bodyweight. Lancet (2011) 378:826-37. doi:10.1016/S0140-6736(11)60812-X

39. Gennemark P, Hjorth S, Gabrielsson J. Modeling energy intake by adding homeostatic feedback and drug intervention. J Pharmacokinet Pharmacodyn (2015) 42:79-96. doi:10.1007/s10928-014-9399-4

40. Cannon B, Nedergaard J. Thermogenesis challenges the adipostat hypothesis for body-weight control. Proc Nutr Soc (2009) 68:401-7. doi:10.1017/ S0029665109990255

41. Cypess AM, Weiner LS, Roberts-Toler C, Franquet Elia E, Kessler SH, Kahn PA, et al. Activation of human brown adipose tissue by a beta3-adrenergic receptor agonist. Cell Metab (2015) 21:33-8. doi:10.1016/j. cmet.2014.12.009

42. McAdam-Marx C, Mukherjee J, Bellows BK, Unni S, Ye X, Iloeje U, et al. Evaluation of the relationship between weight change and glycemic control after initiation of antidiabetic therapy in patients with type 2 diabetes using electronic medical record data. Diabetes Res Clin Pract (2014) 103:402-11. doi:10.1016/j.diabres.2013.12.038

43. Hanssen MJ, Hoeks J, Brans B, van der Lans AA, Schaart G, van den Driessche $\mathrm{JJ}$, et al. Short-term cold acclimation improves insulin sensitivity in patients with type 2 diabetes mellitus. Nat Med (2015) 21:863-5. doi:10.1038/ nm.3891

44. Merovci A, Solis-Herrera C, Daniele G, Eldor R, Fiorentino TV, Tripathy D, et al. Dapagliflozin improves muscle insulin sensitivity but enhances endogenous glucose production. J Clin Invest (2014) 124:509-14. doi:10.1172/ JCI70704

45. Bartesaghi S, Hallen S, Huang L, Svensson PA, Momo RA, Wallin S, et al. Thermogenic activity of UCP1 in human white fat-derived beige adipocytes. Mol Endocrinol (2015) 29:130-9. doi:10.1210/me.2014-1295

46. Shabalina IG, Petrovic N, de Jong JM, Kalinovich AV, Cannon B, Nedergaard J. UCP1 in brite/beige adipose tissue mitochondria is functionally thermogenic. Cell Rep (2013) 5:1196-203. doi:10.1016/j.celrep.2013.10.044

47. Seale P. Transcriptional regulatory circuits controlling brown fat development and activation. Diabetes (2015) 64:2369-75. doi:10.2337/db15-0203

48. Wu J, Jun $\mathrm{H}, \mathrm{McDermott} J R$. Formation and activation of thermogenic fat. Trends Genet (2015) 31:232-8. doi:10.1016/j.tig.2015.03.003

49. Festuccia WT, Blanchard PG, Deshaies Y. Control of brown adipose tissue glucose and lipid metabolism by PPARgamma. Front Endocrinol (2011) 2:84. doi:10.3389/fendo.2011.00084

50. Arch JR. The discovery of drugs for obesity, the metabolic effects of leptin and variable receptor pharmacology: perspectives from beta3-adrenoceptor agonists. Naunyn Schmiedebergs Arch Pharmacol (2008) 378:225-40. doi:10.1007/s00210-008-0271-1

51. Atgie C, D’Allaire F, Bukowiecki LJ. Role of beta1- and beta3-adrenoceptors in the regulation of lipolysis and thermogenesis in rat brown adipocytes. Am J Physiol (1997) 273:C1136-42.

52. Granneman JG. Why do adipocytes make the beta 3 adrenergic receptor? Cell Signal (1995) 7:9-15. doi:10.1016/0898-6568(94)00066-K

53. Lowell BB, Flier JS. Brown adipose tissue, beta 3-adrenergic receptors, and obesity. Annu Rev Med (1997) 48:307-16. doi:10.1146/annurev. med.48.1.307

54. Muzzin P, Revelli JP, Kuhne F, Gocayne JD, McCombie WR, Venter JC, et al. An adipose tissue-specific beta-adrenergic receptor. Molecular cloning and down-regulation in obesity. J Biol Chem (1991) 266:24053-8.

55. Carey AL, Formosa MF, Van Every B, Bertovic D, Eikelis N, Lambert GW, et al. Ephedrine activates brown adipose tissue in lean but not obese humans. Diabetologia (2013) 56:147-55. doi:10.1007/s00125-012-2748-1

56. Cypess AM, Chen YC, Sze C, Wang K, English J, Chan O, et al. Cold but not sympathomimetics activates human brown adipose tissue in vivo. Proc Natl Acad Sci U S A (2012) 109:10001-5. doi:10.1073/ pnas. 1207911109

57. Vosselman MJ, van der Lans AA, Brans B, Wierts R, van Baak MA, Schrauwen $P$, et al. Systemic beta-adrenergic stimulation of thermogenesis is not accompanied by brown adipose tissue activity in humans. Diabetes (2012) 61:3106-13. doi:10.2337/db12-0288

58. Nicholls DG. A history of UCP1. Biochem Soc Trans (2001) 29:751-5. doi:10.1042/bst0290751

59. Ahmadian M, Abbott MJ, Tang T, Hudak CS, Kim Y, Bruss M, et al. Desnutrin/ ATGL is regulated by AMPK and is required for a brown adipose phenotype. Cell Metab (2011) 13:739-48. doi:10.1016/j.cmet.2011.05.002

60. Li Y, Fromme T, Schweizer S, Schottl T, Klingenspor M. Taking control over intracellular fatty acid levels is essential for the analysis of thermogenic function in cultured primary brown and brite/beige adipocytes. EMBO Rep (2014) 15:1069-76. doi:10.15252/embr.201438775

61. Mottillo EP, Bloch AE, Leff T, Granneman JG. Lipolytic products activate peroxisome proliferator-activated receptor (PPAR) alpha and delta in brown adipocytes to match fatty acid oxidation with supply. J Biol Chem (2012) 287:25038-48. doi:10.1074/jbc.M112.374041

62. Zechner R. FLUX FAT: enzymes, regulators, and pathophysiology of intracellular lipolysis. EMBO Mol Med (2015) 7:359-62. doi:10.15252/ emmm.201404846

63. Kajimura S, Saito M. A new era in brown adipose tissue biology: molecular control of brown fat development and energy homeostasis. Annu Rev Physiol (2014) 76:225-49. doi:10.1146/annurev-physiol-021113-170252 
64. Collins S, Daniel KW, Rohlfs EM, Ramkumar V, Taylor IL, Gettys TW. Impaired expression and functional activity of the beta 3- and beta 1-adrenergic receptors in adipose tissue of congenitally obese (C57BL/6J ob/ob) mice. Mol Endocrinol (1994) 8:518-27. doi:10.1210/me.8.4.518

65. Triandafillou J, Himms-Hagen J. Brown adipose tissue in genetically obese (fa/fa) rats: response to cold and diet. Am J Physiol (1983) 244:E145-50.

66. Rogers NH, Landa A, Park S, Smith RG. Aging leads to a programmed loss of brown adipocytes in murine subcutaneous white adipose tissue. Aging Cell (2012) 11:1074-83. doi:10.1111/acel.12010

67. Rafael J, Fesser W, Nicholls DG. Cold adaptation in guinea pig at level of isolated brown adipocyte. Am J Physiol (1986) 250:C228-35.

68. Blondin DP, Labbe SM, Noll C, Kunach M, Phoenix S, Guerin B, et al. Selective impairment of glucose but not fatty acid or oxidative metabolism in brown adipose tissue of subjects with type 2 diabetes. Diabetes (2015) 64:2388-97. doi:10.2337/db14-1651

69. Blondin DP, Labbe SM, Tingelstad HC, Noll C, Kunach M, Phoenix S, et al. Increased brown adipose tissue oxidative capacity in cold-acclimated humans. J Clin Endocrinol Metab (2014) 99:E438-46. doi:10.1210/jc.2013-3901

70. Lee P, Smith S, Linderman J, Courville AB, Brychta RJ, Dieckmann W, et al. Temperature-acclimated brown adipose tissue modulates insulin sensitivity in humans. Diabetes (2014) 63:3686-98. doi:10.2337/db14-0513

71. Rosenwald M, Perdikari A, Rulicke T, Wolfrum C. Bi-directional interconversion of brite and white adipocytes. Nat Cell Biol (2013) 15:659-67. doi:10.1038/ncb2740

72. Soccio RE, Chen ER, Lazar MA. Thiazolidinediones and the promise of insulin sensitization in type 2 diabetes. Cell Metab (2014) 20:573-91. doi:10.1016/j.cmet.2014.08.005

73. Oakes ND, Thalen PG, Jacinto SM, Ljung B. Thiazolidinediones increase plasma-adipose tissue FFA exchange capacity and enhance insulin-mediated control of systemic FFA availability. Diabetes (2001) 50:1158-65. doi:10.2337/ diabetes.50.5.1158

74. Digby JE, Montague CT, Sewter CP, Sanders L, Wilkison WO, O’Rahilly S, et al. Thiazolidinedione exposure increases the expression of uncoupling protein 1 in cultured human preadipocytes. Diabetes (1998) 47:138-41. doi:10.2337/diab.47.1.138

75. Elabd C, Chiellini C, Carmona M, Galitzky J, Cochet O, Petersen R, et al. Human multipotent adipose-derived stem cells differentiate into functional brown adipocytes. Stem Cells (2009) 27:2753-60. doi:10.1002/stem.200

76. Ohno H, Shinoda K, Spiegelman BM, Kajimura S. PPARgamma agonists induce a white-to-brown fat conversion through stabilization of PRDM16 protein. Cell Metab (2012) 15:395-404. doi:10.1016/j.cmet.2012.01.019

77. Petrovic N, Shabalina IG, Timmons JA, Cannon B, Nedergaard J. Thermogenically competent nonadrenergic recruitment in brown preadipocytes by a PPARgamma agonist. Am J Physiol Endocrinol Metab (2008) 295:E287-96. doi:10.1152/ajpendo.00035.2008

78. Sears DD, Hsiao G, Hsiao A, Yu JG, Courtney CH, Ofrecio JM, et al. Mechanisms of human insulin resistance and thiazolidinedione-mediated insulin sensitization. Proc Natl Acad Sci U S A (2009) 106:18745-50. doi:10.1073/pnas.0903032106

79. Burkey BF, Dong M, Gagen K, Eckhardt M, Dragonas N, Chen W, et al. Effects of pioglitazone on promoting energy storage, not expenditure, in brown adipose tissue of obese fa/fa Zucker rats: comparison to CL 316,243. Metabolism (2000) 49:1301-8. doi:10.1053/meta.2000.9524

80. Kelly LJ, Vicario PP, Thompson GM, Candelore MR, Doebber TW, Ventre J, et al. Peroxisome proliferator-activated receptors gamma and alpha mediate in vivo regulation of uncoupling protein (UCP-1, UCP-2, UCP-3) gene expression. Endocrinology (1998) 139:4920-7. doi:10.1210/en.139.12.4920

81. Smith SR, De Jonge L, Volaufova J, Li Y, Xie H, Bray GA. Effect of pioglitazone on body composition and energy expenditure: a randomized controlled trial. Metabolism (2005) 54:24-32. doi:10.1016/j.metabol.2004.07.008

82. Sell H, Berger JP, Samson P, Castriota G, Lalonde J, Deshaies Y, et al. Peroxisome proliferator-activated receptor gamma agonism increases the capacity for sympathetically mediated thermogenesis in lean and ob/ob mice. Endocrinology (2004) 145:3925-34. doi:10.1210/en.2004-0321

83. Festuccia WT, Blanchard PG, Oliveira TB, Magdalon J, Paschoal VA, Richard D, et al. PPARgamma activation attenuates cold-induced upregulation of thyroid status and brown adipose tissue PGC-1alpha and D2. Am J Physiol Regul Integr Comp Physiol (2012) 303:R1277-85. doi:10.1152/ ajpregu.00299.2012
84. Festuccia WT, Blanchard PG, Turcotte V, Laplante M, Sariahmetoglu M, Brindley DN, et al. The PPARgamma agonist rosiglitazone enhances rat brown adipose tissue lipogenesis from glucose without altering glucose uptake. Am J Physiol Regul Integr Comp Physiol (2009) 296:R1327-35. doi:10.1152/ajpregu.91012.2008

85. Bakopanos E, Silva JE. Thiazolidinediones inhibit the expression of beta3-adrenergic receptors at a transcriptional level. Diabetes (2000) 49:2108-15. doi:10.2337/diabetes.49.12.2108

86. Festuccia WT, Oztezcan S, Laplante M, Berthiaume M, Michel C, Dohgu S, et al. Peroxisome proliferator-activated receptor-gamma-mediated positive energy balance in the rat is associated with reduced sympathetic drive to adipose tissues and thyroid status. Endocrinology (2008) 149:2121-30. doi:10.1210/en.2007-1553

87. Bogacka I, Ukropcova B, McNeil M, Gimble JM, Smith SR. Structural and functional consequences of mitochondrial biogenesis in human adipocytes in vitro. J Clin Endocrinol Metab (2005) 90:6650-6. doi:10.1210/jc.2005-1024

88. Bogacka I, Gettys TW, de Jonge L, Nguyen T, Smith JM, Xie H, et al. The effect of beta-adrenergic and peroxisome proliferator-activated receptor-gamma stimulation on target genes related to lipid metabolism in human subcutaneous adipose tissue. Diabetes Care (2007) 30:1179-86. doi:10.2337/dc06-1962

89. Nettles KW, Greene GL. Ligand control of coregulator recruitment to nuclear receptors. Annu Rev Physiol (2005) 67:309-33. doi:10.1146/annurev. physiol.66.032802.154710

90. Lehmann JM, Moore LB, Smith-Oliver TA, Wilkison WO, Willson TM, Kliewer SA. An antidiabetic thiazolidinedione is a high affinity ligand for peroxisome proliferator-activated receptor gamma (PPAR gamma). J Biol Chem (1995) 270:12953-6. doi:10.1074/jbc.270.22.12953

91. Cho N, Momose Y. Peroxisome proliferator-activated receptor gamma agonists as insulin sensitizers: from the discovery to recent progress. Curr Top Med Chem (2008) 8:1483-507. doi:10.2174/156802608786413474

92. Henke BR. 1. Peroxisome proliferator-activated receptor gamma (PPARgamma) ligands and their therapeutic utility. Prog Med Chem (2004) 42:1-53. doi:10.1016/S0079-6468(04)42001-3

93. Nevin DK, Lloyd DG, Fayne D. Rational targeting of peroxisome proliferating activated receptor subtypes. Curr Med Chem (2011) 18:5598-623. doi:10.2174/092986711798347243

94. Savkur RS, Miller AR. Investigational PPAR-gamma agonists for the treatment of Type 2 diabetes. Expert Opin Investig Drugs (2006) 15:763-78. doi:10.1517/13543784.15.7.763

95. Takada I, Makishima M. PPARgamma ligands and their therapeutic applications: a patent review (2008-2014). Expert Opin Ther Pat (2015) 25:175-91. doi:10.1517/13543776.2014.985206

96. Willson TM, Brown PJ, Sternbach DD, Henke BR. The PPARs: from orphan receptors to drug discovery. J Med Chem (2000) 43:527-50. doi:10.1021/ jm990554g

97. Garcia-Vallve S, Guasch L, Tomas-Hernandez S, Del Bas JM, Ollendorff $\mathrm{V}$, Arola L, et al. Peroxisome proliferator-activated receptor gamma (PPARgamma) and ligand choreography: newcomers take the stage. J Med Chem (2015) 58:5381-94. doi:10.1021/jm501155f

98. Abbas A, Blandon J, Rude J, Elfar A, Mukherjee D. PPAR-gamma agonist in treatmentofdiabetes:cardiovascularsafetyconsiderations.CardiovascHematol Agents Med Chem (2012) 10:124-34. doi:10.2174/187152512800388948

99. Bortolini M, Wright MB, Bopst M, Balas B. Examining the safety of PPAR agonists - current trends and future prospects. Expert Opin Drug Saf (2013) 12:65-79. doi:10.1517/14740338.2013.741585

100. Rubenstrunk A, Hanf R, Hum DW, Fruchart JC, Staels B. Safety issues and prospects for future generations of PPAR modulators. Biochim Biophys Acta (2007) 1771:1065-81. doi:10.1016/j.bbalip.2007.02.003

101. Tang WH, Maroo A. PPARgamma agonists: safety issues in heart failure. Diabetes Obes Metab (2007) 9:447-54. doi:10.1111/j.1463-1326.2006.00616.x

102. Germain P, Iyer J, Zechel C, Gronemeyer H. Co-regulator recruitment and the mechanism of retinoic acid receptor synergy. Nature (2002) 415:187-92. doi: $10.1038 / 415187 \mathrm{a}$

103. Hamza MS, PottS, Vega VB, Thomsen JS, Kandhadayar GS, Ng PW, et al. De-novo identification of PPARgamma/RXR binding sites and direct targets during adipogenesis. PLoS One (2009) 4:e4907. doi:10.1371/journal.pone.0004907

104. Bulynko YA, O’Malley BW. Nuclear receptor coactivators: structural and functional biochemistry. Biochemistry (2011) 50:313-28. doi:10.1021/bi101762x 
105. Lonard DM, O'Malley BW. Nuclear receptor coregulators: judges, juries, and executioners of cellular regulation. Mol Cell (2007) 27:691-700. doi:10.1016/j. molcel.2007.08.012

106. Millard CJ, Watson PJ, Fairall L, Schwabe JW. An evolving understanding of nuclear receptor coregulator proteins. J Mol Endocrinol (2013) 51:T23-36. doi:10.1530/JME-13-0227

107. Nolte RT, Wisely GB, Westin S, Cobb JE, Lambert MH, Kurokawa R, et al. Ligand binding and co-activator assembly of the peroxisome proliferator-activated receptor-gamma. Nature (1998) 395:137-43. doi:10.1038/25931

108. Ahmadian M, Suh JM, Hah N, Liddle C, Atkins AR, Downes M, et al. PPARgamma signaling and metabolism: the good, the bad and the future. Nat Med (2013) 19:557-66. doi:10.1038/nm.3159

109. Banks AS, McAllister FE, Camporez JP, Zushin PJ, Jurczak MJ, LaznikBogoslavski D, et al. An ERK/Cdk5 axis controls the diabetogenic actions of PPARgamma. Nature (2015) 517:391-5. doi:10.1038/nature13887

110. Moisan A, Lee YK, Zhang JD, Hudak CS, Meyer CA, Prummer M, et al. White-to-brown metabolic conversion of human adipocytes by JAK inhibition. Nat Cell Biol (2015) 17:57-67. doi:10.1038/ncb3075

111. Dolan JA, Muenkel HA, Burns MG, Pellegrino SM, Fraser CM, Pietri F, et al. Beta-3 adrenoceptor selectivity of the dioxolane dicarboxylate phenethanolamines. J Pharmacol Exp Ther (1994) 269:1000-6.

112. Emorine LJ, Marullo S, Briend-Sutren MM, Patey G, Tate K, DelavierKlutchko C, et al. Molecular characterization of the human beta 3-adrenergic receptor. Science (1989) 245:1118-21. doi:10.1126/science.2570461

113. Lelias JM, Kaghad M, Rodriguez M, Chalon P, Bonnin J, Dupre I, et al. Molecular cloning of a human beta 3 -adrenergic receptor cDNA. FEBS Lett (1993) 324:127-30. doi:10.1016/0014-5793(93)81377-C

114. Hu B, Ellingboe J, Han S, Largis E, Lim K, Malamas M, et al. Novel (4-piperidin-1-yl)-phenyl sulfonamides as potent and selective human beta(3) agonists. Bioorg Med Chem (2001) 9:2045-59. doi:10.1016/ S0968-0896(01)00114-6

115. Buemann B, Toubro S, Astrup A. Effects of the two beta3-agonists, ZD7114 and ZD2079 on 24 hour energy expenditure and respiratory quotient in obese subjects. Int J Obes Relat Metab Disord (2000) 24:1553-60. doi:10.1038/ sj.ijo. 0801452

116. Pietri-Rouxel F, Strosberg AD. Pharmacological characteristics and species-related variations of beta 3 -adrenergic receptors. Fundam Clin Pharmacol (1995) 9:211-8. doi:10.1111/j.1472-8206.1995.tb00288.x

117. Mathvink RJ, Tolman JS, Chitty D, Candelore MR, Cascieri MA, Colwell LF $\mathrm{Jr}$, et al. Discovery of a potent, orally bioavailable beta(3) adrenergic receptor agonist, (R)-N-[4-[2-[[2-hydroxy-2-(3-pyridinyl)ethyl]amino]ethyl]phenyl]-4-[4 -[4-(trifluoromethyl)phenyl]thiazol-2-yl]benzenesulfonamide. $J$ Med Chem (2000) 43:3832-6. doi:10.1021/jm000286i

118. Harada H, Hirokawa Y, Suzuki K, Hiyama Y, Oue M, Kawashima H, et al. Discovery of a novel and potent human and rat beta3-adrenergic receptor agonist, $\quad[3-[(2 \mathrm{R})-[[(2 \mathrm{R})-(3$-chlorophenyl)-2-hydroxyethyl]amino $]$ propyl]-1H-indol-7-yloxy]acetic acid. Chem Pharm Bull (2005) 53:184-98. doi:10.1248/cpb.53.184

119. Takasu T, Ukai M, Sato S, Matsui T, Nagase I, Maruyama T, et al. Effect of (R)-2-(2-aminothiazol-4-yl)-4'-\{2-[(2-hydroxy-2-phenylethyl)amino] ethyl\} acetanilide (YM178), a novel selective beta3-adrenoceptor agonist, on bladder function. J Pharmacol Exp Ther (2007) 321:642-7. doi:10.1124/ jpet.106.115840

120. Blin N, Nahmias C, Drumare MF, Strosberg AD. Mediation of most atypical effects by species homologues of the beta 3-adrenoceptor. Br J Pharmacol (1994) 112:911-9. doi:10.1111/j.1476-5381.1994.tb13167.x

121. Larsen TM, Toubro S, van Baak MA, Gottesdiener KM, Larson P, Saris WH, et al. Effect of a 28-d treatment with L-796568, a novel beta(3)-adrenergic receptor agonist, on energy expenditure and body composition in obese men. Am J Clin Nutr (2002) 76:780-8.

122. Redman LM, de Jonge L, Fang X, Gamlin B, Recker D, Greenway FL, et al. Lack of an effect of a novel beta3-adrenoceptor agonist, TAK-677, on energy metabolism in obese individuals: a double-blind, placebo-controlled randomized study. J Clin Endocrinol Metab (2007) 92:527-31. doi:10.1210/ jc.2006-1740

123. Champigny O, Ricquier D, Blondel O, Mayers RM, Briscoe MG, Holloway $\mathrm{BR}$. Beta 3-adrenergic receptor stimulation restores message and expression of brown-fat mitochondrial uncoupling protein in adult dogs. Proc Natl Acad Sci U S A (1991) 88:10774-7. doi:10.1073/pnas.88.23.10774

124. Weyer C, Tataranni PA, Snitker S, Danforth E Jr, Ravussin E. Increase in insulin action and fat oxidation after treatment with CL 316,243, a highly selective beta3-adrenoceptor agonist in humans. Diabetes (1998) 47:1555-61. doi:10.2337/diabetes.47.10.1555

125. van Baak MA, Hul GB, Toubro S, Astrup A, Gottesdiener KM, DeSmet M, et al. Acute effect of L-796568, a novel beta 3-adrenergic receptor agonist, on energy expenditure in obese men. Clin Pharmacol Ther (2002) 71:272-9. doi:10.1067/mcp.2002.122527

126. Laeger T, Henagan TM, Albarado DC, Redman LM, Bray GA, Noland RC, et al. FGF21 is an endocrine signal of protein restriction. J Clin Invest (2014) 124:3913-22. doi:10.1172/JCI74915

127. Adams AC, Cheng CC, Coskun T, Kharitonenkov A. FGF21 requires betaklotho to act in vivo. PLoS One (2012) 7:e49977. doi:10.1371/journal. pone.0049977

128. Ding X, Boney-Montoya J, Owen BM, Bookout AL, Coate KC, Mangelsdorf DJ, et al. betaKlotho is required for fibroblast growth factor 21 effects on growth and metabolism. Cell Metab (2012) 16:387-93. doi:10.1016/j. cmet.2012.08.002

129. Angelin B, Larsson TE, Rudling M. Circulating fibroblast growth factors as metabolic regulators - a critical appraisal. Cell Metab (2012) 16:693-705. doi:10.1016/j.cmet.2012.11.001

130. Gimeno RE, Moller DE. FGF21-based pharmacotherapy - potential utility for metabolic disorders. Trends Endocrinol Metab (2014) 25:303-11. doi:10.1016/j.tem.2014.03.001

131. Owen BM, Ding X, Morgan DA, Coate KC, Bookout AL, Rahmouni K, et al. FGF21 acts centrally to induce sympathetic nerve activity, energy expenditure, and weight loss. Cell Metab (2014) 20:670-7. doi:10.1016/j. cmet.2014.07.012

132. Chartoumpekis DV, Habeos IG, Ziros PG, Psyrogiannis AI, Kyriazopoulou VE, Papavassiliou AG. Brown adipose tissue responds to cold and adrenergic stimulation by induction of FGF21. Mol Med (2011) 17:736-40. doi:10.2119/ molmed.2011.00075

133. Hanssen MJ, Broeders E, Samms RJ, Vosselman MJ, van der Lans AA, Cheng CC, et al. Serum FGF21 levels are associated with brown adipose tissue activity in humans. Sci Rep (2015) 5:10275. doi:10.1038/srep10275

134. Fisher FM, Kleiner S, Douris N, Fox EC, Mepani RJ, Verdeguer F, et al. FGF21 regulates PGC-1alpha and browning of white adipose tissues in adaptive thermogenesis. Genes Dev (2012) 26:271-81. doi:10.1101/gad.177857.111

135. Lee P, Linderman JD, Smith S, Brychta RJ, Wang J, Idelson C, et al. Irisin and FGF21 are cold-induced endocrine activators of brown fat function in humans. Cell Metab (2014) 19:302-9. doi:10.1016/j.cmet.2013.12.017

136. Hondares E, Gallego-Escuredo JM, Flachs P, Frontini A, Cereijo R, Goday $\mathrm{A}$, et al. Fibroblast growth factor-21 is expressed in neonatal and pheochromocytoma-induced adult human brown adipose tissue. Metabolism (2014) 63:312-7. doi:10.1016/j.metabol.2013.11.014

137. Camporez JP, Jornayvaz FR, Petersen MC, Pesta D, Guigni BA, Serr J, et al. Cellular mechanisms by which FGF21 improves insulin sensitivity in male mice. Endocrinology (2013) 154:3099-109. doi:10.1210/en.2013-1191

138. Emanuelli B, Vienberg SG, Smyth G, Cheng C, Stanford KI, Arumugam $\mathrm{M}$, et al. Interplay between FGF21 and insulin action in the liver regulates metabolism. J Clin Invest (2015) 125:458. doi:10.1172/JCI80223

139. Samms RJ, Smith DP, Cheng CC, Antonellis PP, Perfield JW II, Kharitonenkov A, et al. Discrete aspects of FGF21 in vivo pharmacology do not require UCP1. Cell Rep (2015) 11:991-9. doi:10.1016/j.celrep.2015.04.046

140. Veniant MM, Sivits G, Helmering J, Komorowski R, Lee J, Fan W, et al. Pharmacologic effects of FGF21 are independent of the "browning" of white adipose tissue. Cell Metab (2015) 21:731-8. doi:10.1016/j.cmet.2015.04.019

141. Keipert S, Kutschke M, Lamp D, Brachthauser L, Neff F, Meyer CW, et al. Genetic disruption of uncoupling protein 1 in mice renders brown adipose tissue a significant source of FGF21 secretion. Mol Metab (2015) 4:537-42. doi:10.1016/j.molmet.2015.04.006

142. Ukropec J, Anunciado RP, Ravussin Y, Hulver MW, Kozak LP. UCP1independent thermogenesis in white adipose tissue of cold-acclimated Ucp1-/- mice. J Biol Chem (2006) 281:31894-908. doi:10.1074/jbc. M606114200 
143. Dong JQ, Rossulek M, Somayaji VR, Baltrukonis D, Liang Y, Hudson K, et al. Pharmacokinetics and pharmacodynamics of PF-05231023, a novel long-acting FGF21 mimetic, in a first-in-human study. Br J Clin Pharmacol (2015) 80(5):1051-63. doi:10.1111/bcp.12676

144. Gaich G, Chien JY, Fu H, Glass LC, Deeg MA, Holland WL, et al. The effects of LY2405319, an FGF21 analog, in obese human subjects with type 2 diabetes. Cell Metab (2013) 18:333-40. doi:10.1016/j.cmet.2013.08.005

145. Kolumam G, Chen MZ, Tong R, Zavala-Solorio J, Kates L, van Bruggen N, et al. Sustained brown fat stimulation and insulin sensitization by a humanized bispecific antibody agonist for fibroblast growth factor receptor 1/betaKlotho complex. EBioMedicine (2015) 2:730-43. doi:10.1016/j.ebiom.2015.05.028
Conflict of Interest Statement: The authors declare that the research was conducted in the absence of any commercial or financial relationships that could be construed as a potential conflict of interest.

Copyright (๑ 2015 Peng, Gennemark, O'Mahony and Bartesaghi. This is an open-access article distributed under the terms of the Creative Commons Attribution License (CC BY). The use, distribution or reproduction in other forums is permitted, provided the original author(s) or licensor are credited and that the original publication in this journal is cited, in accordance with accepted academic practice. No use, distribution or reproduction is permitted which does not comply with these terms. 